OPEN ACCESS

Edited by:

David Ong,

Franciscus Gasthuis \& Vlietland

Netherlands

Reviewed by:

Guillaume Desoubeaux,

Université de Tours, France

Diego Hernando Caceres,

Centers for Disease Control and Prevention (CDC), United States

Antoine Adenis,

Centre Hospitalier de Cayenne,

French Guiana

*Correspondence:

M. Teresa Martín-Gómez

mtmartin@vhebron.net

Specialty section:

This article was submitted to

Fungi and Their Interactions,

a section of the journal

Frontiers in Microbiology

Received: 15 November 2019

Accepted: 04 March 2020

Published: 24 March 2020

Citation:

Buitrago $\mathrm{MJ}$ and

Martín-Gómez MT (2020) Timely

Diagnosis of Histoplasmosis

in Non-endemic Countries:

A Laboratory Challenge.

Front. Microbiol. 11:467.

doi: 10.3389/fmicb.2020.00467

\section{Timely Diagnosis of Histoplasmosis in Non-endemic Countries: A Laboratory Challenge}

\author{
María José Buitrago ${ }^{1}$ and M. Teresa Martín-Gómez²* \\ ${ }^{1}$ Mycology Reference Laboratory, National Centre of Microbiology, Instituto de Salud Carlos III, Madrid, Spain, ${ }^{2}$ Microbiology \\ Department, Vall d'Hebron University Hospital, Barcelona, Spain
}

Human histoplasmosis is a fungal infection caused by the inhalation of microconidia of the thermally dimorphic fungi Histoplasma capsulatum. Autochthonous cases of histoplasmosis have been diagnosed in almost every country, but it is considered an endemic infection in specific areas of the world. Many of them are popular travel destinations or the source of migratory movements. Thus, the vast majority of the registered cases in non-endemic countries are imported. They correspond to people having been exposed to the fungus in endemic locations as immigrants, expatriates, transient workers or tourists, with reported cases also associated to organ donation. Misdiagnosis and delays in initiation of treatment are not uncommon in cases of imported histoplasmosis. They are associated to high fatality-rates specially in patients with compromised cellular immunity in which progressive disseminated forms develop. The diagnosis of this infection in non-endemic countries is hampered by the lack of clinical suspicion and a dearth of available diagnostic tools adequate to offer rapid and accurate results. Non-culture-based assays such as nucleic-acid amplification tests present as a suitable alternative in this situation, offering improved sensitivity and specificity, shortened turnaround time, and increased biosafety by avoiding culture manipulation. In non-endemic regions, molecular techniques are being used mainly in laboratories from countries that have registered an increase in the incidence of imported cases. However, the number of published techniques is limited and lack consensus. Efforts are currently under way to standardize nucleic acid amplificationbased techniques for its implementation in areas registering a rising number of imported cases.

\section{Keywords: histoplasmosis, laboratory, diagnosis, non-endemic areas, PCR}

We are living an era of massive population movements due to immigration, volunteering, and affordable adventure travels to areas not previously accessible to the general public. This opens the door to the emergence of exotic infections in countries where such illnesses are infrequent (Barboza and Ouatresous, 2007; Schlagenhauf et al., 2015). That is the case of histoplasmosis (Manfredi et al., 1994; Bahr et al., 2015).

Human histoplasmosis is a fungal infection caused by inhalation of microconidia of the thermally dimorphic fungi Histoplasma capsulatum v. capsulatum and $H$. capsulatum v. duboisii. In immunocompetent individuals, exposure to this fungus usually remains unnoticed or manifests as a flu-like respiratory episode, whereas immunocompromised patients are exposed to life-threatening disseminated infections (Wheat et al., 2016). 
The distribution of $H$. capsulatum v. duboisii seem to be restricted to Sub-Saharian Africa. H. capsulatum v. capsulatum, in contrast, can be found irregularly distributed worldwide. The latter is more prevalent in the Eastern Coast of United States, Central-America, Northern countries of South-America, SouthEastern Asia, and territories crossed by the Yangtze River and the Brahmaputra River, and is rarely found in more temperate regions of the world (Antinori, 2014; Baker et al., 2019). Thus, although autochthonous cases of histoplasmosis have been described in many countries, it is commonly considered an "endemic infection" only in specific areas, many of which are popular travel destinations (UNWTO, 2019) or the source of migratory movements (International Organization for Migration, 2018).

\section{HISTOPLASMOSIS IN NON-ENDEMIC COUNTRIES: THE EXTENT OF THE PROBLEM}

Histoplasmosis is not a notifiable disease, and it is not included in most Public Health surveillance systems, making difficult to quantify its real burden (Nacher et al., 2018). Incomplete data exist on the incidence and prevalence of this infection in non-endemic countries. In Spain, a prevalence of 0.31 cases (SD 0.1) per 100,000 population-year has been reported, but this may be an underestimation, as only patients seeking for medical advice upon arrival from a presumed endemic region were included (Molina-Morant et al., 2018). Similar studies are lacking in other non-endemic regions. Available figures indicate that histoplasmosis is the most frequent imported mycosis (Salzer et al., 2018): cases correspond to immigrants, expatriates, transient workers or tourists having had Histoplasma exposure in endemic areas (Molina-Morant et al., 2018; Salzer et al., 2018; Staffolani et al., 2018). Transmission related to solid organ donation has been sporadically described (Kamei et al., 2003; Ashbee et al., 2008; Berger, 2018).

On the basis of histoplasmin skin test studies, it has been estimated that up to $20 \%$ of travelers returning from Latin America may have had contact with Histoplasma (Norman et al., 2009). Activities related to cave exploration, or exposure to soils enriched in nitrogen from bats and birds droppings are the common denominator of up to $29.4 \%$ cases of imported histoplasmosis (Kamei et al., 2003; Ashbee et al., 2008). Clusters of cases are associated to groups undergoing leisure or professional activities in high risk locations (Alonso et al., 2007; Cottle et al., 2013), and sum up to $56.2 \%$ of well-documented published cases in European travelers (Staffolani et al., 2018).

Spain along with France and Italy have reported the largest numbers of sporadic cases involving travelers and immigrants (Loulergue et al., 2007; Peigne et al., 2011; Buitrago and Cuenca-Estrella, 2012; Nacher et al., 2018; Staffolani et al., 2018). They accumulate up to $64.1 \%$ of the cases diagnosed in immunocompetent European travelers (Staffolani et al., 2018), and concentrate $66.4 \%$ of travel-related cases belonging to a cluster. Isolated cases have been communicated in several other European countries (Ashbee et al., 2008; Doleschal et al., 2016;
Lindner et al., 2018) as well as in Asia (Cho et al., 2018) and the MiddleEast (Segel et al., 2015).

\section{CLINICAL PRESENTATION}

Most histoplasmosis cases detected in areas of low-endemicity occur following three main patterns. The most difficult to detect corresponds to immunocompetent individuals exposed to a low infectious inoculum that experience an asymptomatic seroconversion or a mild flu-like respiratory episode. This is presumedly the most frequent form of imported histoplasmosis (Norman et al., 2009). After return to their country of origin, these cases usually remain unnoticed unless patients are investigated in the setting of an outbreak (Staffolani et al., 2018). Some patients fail to clear the infection and evolve inadvertently to a chronic form with pulmonary nodules. They may be incidentally found later in life, being commonly misdiagnosed as lung cancer or tuberculosis (Ashbee et al., 2008; Norman et al., 2009; Wheat et al., 2016; Azar et al., 2018; Oladele et al., 2018). Because of the wide time gap between primary exposure and diagnosis, it is hard to establish an epidemiological link, of help to guide medical interventions.

The second pattern is seen in cases of massive Histoplasma exposure (i.e., high-risk activities in heavily contaminated areas), after which immunocompetent patients may develop an acute pneumonia days to a few weeks later. This presentation was reported in $90.7 \%$ of the cases included in the Staffolani's review (Staffolani et al., 2018).

The third pattern corresponds to progressive disseminated histoplasmosis, usually seen in patients with compromised cellular immunity, mainly related to HIV infection, but also to organ transplant and biological therapies, in particular antiTNF- $\alpha$ drugs (Baddley et al., 2018). This scenario is frequently associated to individuals that have resided for long periods of time in endemic areas before moving to receptor countries, but and manifests in the setting of an acquired immunologic incompetence (Ashbee et al., 2008; Norman et al., 2009).

Risk of reactivation exists even decades after the initial infection (Loulergue et al., 2007; Richaud et al., 2014). Up to 25\% of cases registered in European travelers developed 5 years after exposure, and $41 \%$ of disseminated forms were reactivations of infections occurring at least 5 years before (Ashbee et al., 2008). This event is usually related to an acquired immunocompromise.

The mortality rate of cases diagnosed in non-endemic areas depends on the clinical form, and the immune status of the host, but also on the diagnostic and therapeutic promptness. For immunocompetent individuals it ranges between 2 and 17.4\% (Kamei et al., 2003; Molina-Morant et al., 2018; Salzer et al., 2018). A $10 \%$ attributable mortality is reported for histoplasmosis in solid organ transplant recipients (Gajurel et al., 2017). The highest fatality rates are associated to misdiagnosed forms of progressive disseminated histoplasmosis: $42 \%$ mortality if treatment is delayed, and $100 \%$ if antifungal therapy is not prescribed (Ashbee et al., 2008; Scheel et al., 2014). Some cases are only revealed at autopsy (Kamei et al., 2003; Antinori et al., 2006; Denning, 2016). 


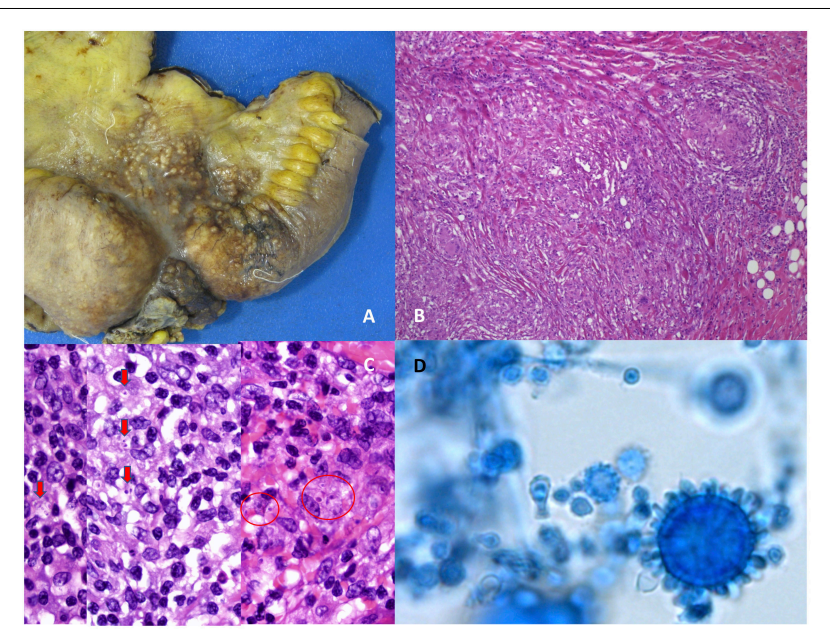

FIGURE 1 | Morphological appearance of Histoplasma capsulatum var. capsulatum in culture and in affected tissues. Images (A-C) are courtesy of Dr. Steffania Landolfi. (A) Surgically excised ileum showing stenosis and multiple macroscopic nodules from a case of disseminated histoplasmosis with intestinal involvement. (B) Tipical appearance of granulomas in tissue, hematoxilin-Eosin. (C) Intracellular yeasts surrounded by a clear area resembling a pseudocapsula (Hematoxilin-Eosin staining). (D) Tuberculate macroconidia of Histoplasma capsulatum var. capsulatum in culture.

\section{HANDICAPS OF LABORATORY DIAGNOSIS IN NON-ENDEMIC AREAS}

The two main diagnostic handicaps in non-endemic areas are the usually low index of suspicion, and the scarceness of tools for a fast and accurate identification of the infection.

Conventional laboratory tests for the diagnosis of histoplasmosis include mycological cultures and histopathology of affected organs and tissues (Figure 1). Isolation of the fungus in culture is considered the gold standard for diagnosis. H. capsulatum can grow in mycological media of common use in routine laboratories, and current MALDI-TOF systems can provide a presumptive identification (Panda et al., 2015; Rizzato et al., 2015; Rychert et al., 2018; Valero et al., 2018). Cultures, however, have well-known limitations, i.e., slowness, suboptimal sensitivity, and requirement of BSL3 facilities to manipulate them (Kauffman, 2009). Typical tuberculate macroconidia closely resemble the saprophyte Sepedonium, and microconidia can be misidentified as Chrysosporium. The histopathological observation also requires skilled personnel. A plethora of findings complicates the microscopic diagnosis to pathologists non-familiar with this infection: images range from localized granulomas to extensive aggregates of macrophages fulfilled with small yeasts surrounded by pseudocapsules (Woods and Schnadig, 2003). Intracellular yeasts are often confused with Leishmania spp., Cryptococcus or C. glabrata by non-expert observers (Wheat, 2003; Wheat et al., 2016).

Complement fixation (CF) or Immunodiffusion (ID) are common techniques used for Histoplasma antibody detection. Their sensitivity greatly varies depending on the clinical form and the immune status of the host. Antibody detection is of limited usefulness in severely immunocompromised individuals, and to diagnose acute infections in early phases (Azar and Hage, 2017). In non-endemic areas serology is usually performed in reference centers as a complementary tool, meaning that results are not readily available. Despite this, antibody detection was used in the diagnostic workup of $74.7 \%$ cases reported in immunocompetent European travelers (Staffolani et al., 2018). Novel FDA cleared tests seem to be of help in the differential diagnosis of pulmonary nodules, but currently they are not available overseas (Deppen et al., 2019).

Histoplasma antigen detection in body fluids is currently considered the most sensitive and quickest technique to diagnose this infection (Azar and Hage, 2017). It is particularly useful in progressive disseminated forms, and it has proven its applicability to infected animals that may act as potential reservoirs for humans (Cunningham et al., 2015; Rothenburg et al., 2019). Combined detection in serum and urine seem to provide the best diagnostic performance, with some differences in the diagnostic yield between FDA cleared tests (Theel et al., 2013; FandiñoDevia et al., 2016; Azar and Hage, 2017; Torres-González et al., 2018). Antigen detection provides a clear improvement for the management of histoplasmosis, especially in highly endemic areas where this infection frequently coexists with tuberculosis (Bansal et al., 2019), and recently it has been included in the WHO list of essential diagnostic test ${ }^{1}$. Despite FDA-approved commercial tests are available, their use is mostly restricted to developed endemic areas (Bongomin et al., 2019a). There is little data regarding its performance in non-endemic areas. The reported use of antigen detection in non-United States cases of imported histoplasmosis is very limited: performance of an antigen test (in urine and/or serum) was declared only in 9 out of 319 cases of histoplasmosis in immunocompetent travelers diagnosed out of the United States (Staffolani et al., 2018). Even in non-endemic areas of the United States, the use of the EIA antigen detection has been seldom reported (Benedict et al., 2015). The underlying reason may be at least partially related to the overall scarcity of imported cases, making the test non-costeffective in settings of no endemicity.

\section{MOLECULAR ALTERNATIVES TO DIAGNOSE HISTOPLASMOSIS}

Historically, antigen detection tests use to be not available in non-endemic regions, so molecular techniques may represent a suitable alternative for a rapid diagnosis. They offer the opportunity to shorten turnaround times, and to diminish the risk of laboratory-acquired infection where laboratory personnel is not used to handle Histoplasma positive cultures. In nonendemic regions, the use of molecular techniques has been described mainly in countries that have registered an increase in the incidence of imported cases, such as Spain (Buitrago et al., 2011). Staffolani reflected the sporadic use of PCR techniques in travelers (Staffolani et al., 2018) and, more recently, a case

\footnotetext{
${ }^{1}$ https://www.who.int/medical_devices/publications/Standalone_document_v8. pdf
} 
TABLE 1 | Characteristics of published nucleic acid amplification assays based on conventional and Real Time PCR for the diagnosis of histoplasmosis.

\begin{tabular}{|c|c|c|c|c|c|c|}
\hline References & Country & PCR assay & Target & Clinical samples & $\begin{array}{l}\text { Sensitivity } \\
\text { (samples tested) }\end{array}$ & Specificity \\
\hline Bialek et al., 2001* & Germany/United States & $\begin{array}{l}\text { Conventional } \\
\text { (nested) }\end{array}$ & $18 \mathrm{~S}$ rDNA & $\begin{array}{l}\text { Blood, spleen, lung } \\
\text { (mice) }\end{array}$ & $83.1 \%$ & ND \\
\hline Rickerts et al., 2002 & Germany/United States & $\begin{array}{l}\text { Conventional } \\
\text { (nested) }\end{array}$ & $\begin{array}{l}100-k D a-l i k e \\
\text { protein Gene }\end{array}$ & Biopsy & $70 \%$ & $100 \%$ \\
\hline Guedes et al., $2003^{1}$ & Brazil & Conventional & M antigen gene & $\mathrm{NO}^{1}$ & $100 \%$ & $100 \%$ \\
\hline Bracca et al., 2003 & Argentina & $\begin{array}{l}\text { Conventional } \\
\text { (semi-nested) }\end{array}$ & M antigen gene & Biopsy, blood, mucose & ND (30) & ND \\
\hline $\begin{array}{l}\text { Martagon-Villamil et al., } \\
2003^{2}\end{array}$ & United States & Real time & ITS rDNA & $\begin{array}{l}\text { BAL, lung biopsy, bone } \\
\text { marrow }\end{array}$ & $100 \%(3)$ & $100 \%$ \\
\hline Maubon et al., 2007 & French Guiana & Bialek et al., 2002 & $\begin{array}{l}100-k D a-l i k e \\
\text { protein Gene }\end{array}$ & $\begin{array}{l}\text { Blood, serum, BAL, } \\
\text { BAS, biopsy, CSF, } \\
\text { others }\end{array}$ & $100 \%(40)$ & $100 \%$ \\
\hline Buitrago et al., 2011 & Spain & Real time & ITS rDNA & $\begin{array}{l}\text { Blood, serum, bone } \\
\text { marrow, sputum, BAS, } \\
\text { BAL, biopsy, CSF, } \\
\text { others }\end{array}$ & $\begin{array}{l}\text { 89\% Proven H (54); } \\
60 \% \text { probable H } \\
\text { (13) }\end{array}$ & $100 \%$ \\
\hline Simon et al., 2010 & French Guiana & Real time & ITS rDNA & $\begin{array}{l}\text { BAL, biopsy, bone } \\
\text { marrow, CSF }\end{array}$ & $95,4 \%(348)$ & $96 \%$ \\
\hline Gago et al., 2014 & Spain & Multiplex real time & ITS rDNA & $\begin{array}{l}\text { BAL, biopsy, serum, } \\
\text { bone marrow }\end{array}$ & $92.5 \%(72)$ & $100 \%$ \\
\hline López et al., 2017³* & Colombia & Real time PCR & $\begin{array}{l}\text { M antigen gene } \mathrm{H} \\
\text { antigen gene ITS } \\
\text { rDNA }\end{array}$ & Lung biopsy (mice) & ND & $N D^{3}$ \\
\hline
\end{tabular}

*Murine model; (1) tested on DNA from strains; (2) tested mainly on DNA from strains; (3) comparative analysis of three techniques; BAL, bronchoalveolar lavage; BAS, broncho aspirate; Proven H, proven histoplamosis by EORTC/MSG criteria; Probable H, probable histoplasmosis by EORTC/MSG criteria; ND, no data.

was diagnosed with the use of a panfungal assay in Germany (Lindner et al., 2018). Beside this, PCR-based techniques have been claimed to be of help in the detection of environmental reservoirs, and in the design of strategies of intervention to prevent exposure risk (Gómez et al., 2018, 2019).

No commercial PCR-based test has been approved for in vitro diagnosis yet, but published techniques show promising results. In a recent meta-analysis Caceres and coworkers reported an overall sensitivity and specificity (95\% CI) of 95.4 (88.8101.9) and 98.7 (95.7-101.7) respectively in cases of progressive disseminated histoplasmosis of HIV + patients (Caceres et al., 2019). To date, the reported assays target different regions in the genome, being the most successful the ITS multicopy region of the ribosomal DNA, and genes encoding the $\mathrm{M}$ antigen or the $100-\mathrm{kDa}$-like protein. Techniques encompass conventional and nested PCR, as well as the more user-friendly and less cumbersome real-time PCR (table 1). A Reference Laboratory in Spain has developed various real time PCR-based assays, showing an excellent performance for the diagnosis of 39 cases of histoplasmosis (Buitrago et al., 2006, 2011; Gago et al., 2014). Samples were obtained from cases of probable infection in immunocompetent travelers (23\%), and of proven histoplasmosis diagnosed in immigrants (77\%), 97\% of them having AIDS as underlying disease. The sensitivity of the PCR for disseminated disease was $89 \%$ showing superiority over mycological culture (73\%) and antibody detection (40\%) (Buitrago et al., 2011). An interesting multiplex approach developed by the same group targets mixed infections with Pneumocystis jirovecii and Cryptococcus neoformans, common opportunistic fungal pathogens of HIV-infected patients. This design showed an overall sensitivity of 93 and $100 \%$ specificity.

Regarding the best samples to test, different types of specimens have been studied, including respiratory secretions, biopsies, bone marrow, blood, or sera. Good performance of respiratory samples and biopsies has been reported (Buitrago et al., 2011). The sensitivity for blood and bone marrow specimens reached $100 \%$ in immunocompromised patients with disseminated disease (Maubon et al., 2007), but was more modest in immunocompetent patients (Buitrago et al., 2011) reflecting the lower amount of circulating DNA circulating in these patients. An important point was the increased sensitivity obtained by testing more than one sample per patient in cases with extra-pulmonary involvement (Gago et al., 2014). Overall, although the diagnostic yield seem variable depending on the disease stage, clinical form, and type of specimen, PCR based techniques may be the answer to provide the much desired rapid results, particularly to diagnose severe cases in non-endemic locations (Vasconcellos et al., 2019).

As compared to other PCR modalities, isothermal nucleic acid amplification techniques are considered cheaper and more userfriendly. No sophisticated equipment is required, and handling can be done by personnel lacking expertise in molecular test (Lee, 2017). However, limited attempts have been made to design isothermal assays. All of them dealt with progressive disseminated histoplasmosis samples of $\mathrm{HIV}+$ patients from endemic countries, with reasonably good results (Scheel et al., 2014; Zatti et al., 2019). Their diagnostic yield varied greatly depending on the type of sample tested: an $83 \%$ sensitivity was 
reported for blood and bone marrow as compared to a nested PCR targeting the Hcp100 gene (Zatti et al., 2019), whereas a more modest $67 \%$ sensitivity was achieved in antigen positive urine samples. Altogether, isothermal assays could become suitable for use as a complementary diagnostic test in low-income countries, and potentially useful techniques for implementation in non-endemic areas.

Major drawbacks of in-house molecular tests are the lack standardization and consensus among laboratories. These aspects have been addressed by the only inter-laboratory study focused on molecular techniques for the diagnosis of histoplasmosis published to date (Buitrago et al., 2013). Seven PCR protocols (conventional and real time) were compared, with an overall sensitivity and specificity of 86 and $100 \%$ respectively. The results of this work led the authors to conclude that multicopy targets were the best option when designing an assay as they provide and increase in sensitivity without decreasing specificity; real time PCR proved to be more advantageous than conventional PCR. In contrast, one study limited to a small number of samples from a single laboratory showed a better sensitivity of nested PCR assays as compared to designs based on cycling-probe real-time PCR (Muraosa et al., 2016). Such differences highlight the need of collaborative networks to assess the diagnostic yield of different molecular assay designs for the diagnosis of histoplasmosis, particularly in areas of low prevalence.

\section{FUTURE DIRECTIONS AND CONCLUSION}

Education has proven to be an essential tool to increase the recognition of cases in endemic resource-constrained settings (Caceres et al., 2015), and also, it may be a future strategy to implement in non-endemic areas. Other pillars of utmost importance to effectively fight against histoplasmosis should be to consider it a notifiable infection, to quantify the real extent of the problem (Bongomin et al., 2019b; Staffolani et al., 2020), and to put into practice the use of rapid and reliable tools to detect and control potential environmental and animal sources of human infection (Cunningham et al., 2015; Gómez et al., 2018, 2019; Rothenburg et al., 2019).

Sadly, histoplasmosis is not classified as a neglected disease by organizations involved in Public Health, and published cases are thought to be just the tip of the iceberg. This hampers the development of affordable and accurate diagnostic tools. Efforts, however, are under way. A Colombian group is working on the development of an IGRA-based assay with promising preliminary

\section{REFERENCES}

Alonso, D., Muñoz, J., Letang, E., Salvadó, E., Cuenca-Estrella, M., Maria José Buitrago, M. J., et al. (2007). Imported acute histoplasmosis with rheumatologic manifestations in spanish travelers. J. Travel. Med. 14, 338-342. doi: 10.1111/j. 1708-8305.2007.00138.x

Antinori, S. (2014). Histoplasma capsulatum: more widespread than previously thought. Am. J. Trop. Med. Hyg. 90, 982-983. doi: 10.4269/ajtmh.14-0175 results, and a huge potential for the diagnosis of subclinical infections regardless of the immune status of the host (RubioCarrasquilla et al., 2019); more results are awaited. A lateral flow device (LFD) for the detection of Histoplasma antigen in serum has been developed recently showing an excellent sensitivity, and extensive validation in non-progressive disseminated cases is expected (Cáceres et al., 2019). Molecular test might be part of the diagnostic armamentarium in settings where clinicians and laboratory personnel are not familiar with this pathogen. Reference laboratories from non-endemic regions with growing number of histoplasmosis cases are accumulating experience, and they are developing new assays that could also be of great help in areas of high endemicity.

Much remains to be done to improve the laboratory diagnosis of imported histoplasmosis. Efforts include extensive standardization and validation of already developed PCR-based techniques, and definition of the diagnostic yield in different types of samples and clinical settings. Initiatives to perform multicenter studies in non-endemic regions are being launched (Buitrago MJ, personal communication) to achieve a consensus on technical issues such as the best DNA extraction method or the most suitable targets, among others.

In conclusion, histoplasmosis is a primary fungal infection increasingly seen in non-endemic countries as a result of recreational travels and migratory movements. In receptor areas timely diagnosis is hampered by the lack of clinical awareness, and the scarcity of laboratory techniques able to provide accurate results with a short turn-around time regardless of the immune status of the host and the extent of the disease. Molecular techniques are seen as a suitable alternative for this purpose in areas of low prevalence. Much needed efforts to standardize such assays and to define their diagnostic yield are in progress. Molecular test promise to be of great help nonendemic areas, and as adjunctive tests for the laboratory diagnosis of histoplasmosis in areas of high endemicity.

\section{AUTHOR CONTRIBUTIONS}

$\mathrm{MB}$ and MM-G contributed equally to the design, elaboration, and review of this manuscript.

\section{ACKNOWLEDGMENTS}

The authors are thankful to Dr. Steffania Landolfi for kindly providing the histopathology images that illustrate this manuscript.

Antinori, S., Magni, C., Nebuloni, M., Parravicini, C., Corbellino, M., Sollima, S., et al. (2006). Histoplasmosis among human immunodeficiency virus-infected people in europe. Medicine 85, 22-36. doi: 10.1097/01.md.0000199934.38120. d4

Ashbee, H. R., Evans, E. G. V., Viviani, M. A., Dupont, B., Chryssanthou, E., Surmont, I., et al. (2008). Histoplasmosis in Europe: report on an epidemiological survey from the European confederation of medical mycology working group. Med. Mycol. 46, 57-65. doi: 10.1080/13693780701591481 
Azar, M. M., and Hage, C. A. (2017). Laboratory diagnostics for histoplasmosis. J. Clin. Microbiol. 55, 1612-1620. doi: 10.1128/JCM.02430-16

Azar, M. M., Zhang, X., Assi, R., Hage, C., Wheat, L. J., and Malinis, M. F. (2018). Clinical and epidemiological characterization of histoplasmosis cases in a nonendemic area. Connecticut, United States. Med. Mycol. 56, 896-899. doi: $10.1093 / \mathrm{mmy} / \mathrm{myx} 120$

Baddley, J. W., Cantini, F., Goletti, D., Gómez-Reino, J. J., Mylonakis, E., SanJuan, R., et al. (2018). ESCMID study group for infections in compromised hosts (ESGICH) consensus document on the safety of targeted and biological therapies: an infectious diseases perspective (soluble immune effector molecules [I]: anti-tumor necrosis factor- $\alpha$ agents). Clin. Microbiol. Infect. 24, S10-S20. doi: 10.1016/j.cmi.2017.12.025

Bahr, N. C., Antinori, S., Wheat, L. J., and Sarosi, G. A. (2015). Histoplasmosis infections worldwide: thinking outside of the Ohio River Valley. Curr. Trop. Med. Rep. 2, 70-80. doi: 10.1007/s40475-015-0044-0

Baker, J., Setianingrum, F., Wahyuningsih, R., and Denning, D. W. (2019). Mapping histoplasmosis in South East Asia - implications for diagnosis in AIDS. Emerg. Microbes Infect. 8, 1139-1145. doi: 10.1080/22221751.2019. 1644539

Bansal, N., Sethuraman, N., Gopalakrishnan, R., Ramasubramanian, V., Kumar, D. S., Nambi, P. S., et al. (2019). Can urinary Histoplasma antigen test improve the diagnosis of histoplasmosis in a tuberculosis endemic region? Mycoses 62, 502-507. doi: 10.1111/myc.12902

Barboza, P., and Ouatresous, I. (2007). Globalization, emergence and importation of infectious diseases. Rev. Prat. 57, 867-873.

Benedict, K., Thompson, G. R., Stan Deresinski, S., and Chiller, T. (2015). Mycotic infections acquired outside areas of known endemicity. United States. Emerg. Infect. Dis. 21, 1935-1941. doi: 10.3201/eid2111.141950

Berger, S. (2018). GIDEON Guide to Outbreaks. Available online at https://www.gideononline.com/ebooks/outbreaks/

Bialek, R., Feucht, A., Aepinus, C., Just-Nübling, G., Robertson, V. J., Knobloch, J., et al. (2002). Evaluation of two nested PCR assays for detection of Histoplasma capsulatum DNA in human tissue. J. Clin. Microbiol. 40, 1644-1647. doi: 10. $1128 / \mathrm{jcm} .40 .5 .1644-1647.2002$

Bialek, R., Fischer, J., Feucht, A., Najvar, L. K., Dietz, K., Knobloch, J., et al. (2001). Diagnosis and monitoring of murine histoplasmosis by a nested PCR assay. J. Clin. Microbiol. 39, 1506-1509. doi: 10.1128/JCM.39.4.1506-1509.2001

Bongomin, F., Govender, N. P., Chakrabarti, A., Robert-Gangneux, F., Boulware, D. R., Zafar, A., et al. (2019a). Essential in vitro diagnostics for advanced HIV and serious fungal siseases: international experts' consensus recommendations. Eur. J. Clin. Microbiol. Infect. Dis. 38, 1581-1584. doi: 10.1007/s10096-01903600-4

Bongomin, F., Kwizera, R., and Denning, D. W. (2019b). Getting histoplasmosis on the map of international recommendations for patients with advanced HIV disease. J. Fungi. 5:E80. doi: 10.3390/jof5030080

Bracca, A., Tosello, M. E., Girardini, J. E., Amigot, S. L., Gomez, C., and Serra, E. (2003). Molecular detection of Histoplasma capsulatum var. capsulatum in human clinical samples. J. Clin. Microbiol. 41, 1753-1755. doi: 10.1128/jcm.41. 4.1753-1755.2003

Buitrago, M. J., Berenguer, J., Mellado, E., Rodríguez-Tudela, J. L., and CuencaEstrella, M. (2006). Detection of imported histoplasmosis in serum of HIVinfected patients using a real-time PCR-based assay. Eur. J. Clin. Microbiol. Infect. Dis. 25, 665-668. doi: 10.1007/s10096-006-0207-y

Buitrago, M. J., Bernal-Martínez, L., Castelli, M. V., Rodríguez-Tudela, J. L., and Cuenca-Estrella, M. (2011). Histoplasmosis and paracoccidioidomycosis in a non-endemic area: a review of cases and diagnosis. J. Trav. Med. 18, 26-33. doi: 10.1111/j.1708-8305.2010.00477.x

Buitrago, M. J., Canteros, C. E., Frías De León, G., González, A., MarquesEvangelista, De Oliveira, M., et al. (2013). Comparison of PCR protocols for detecting Histoplasma capsulatum DNA through a multicenter study. Rev. Iberoam. Micol. 30, 256-260. doi: 10.1016/j.riam.2013.03.004

Buitrago, M. J., and Cuenca-Estrella, M. (2012). Current epidemiology and laboratory diagnosis of endemic mycoses in Spain. Enferm. Infec. Microbiol. Clin. 30, 407-413. doi: 10.1016/j.eimc.2011.09.014

Cáceres, D. H., Gómez, B. L., Tobón, A. M., Chiller, T. M., and Lindsley, M. D. (2019). Evaluation of a Histoplasma antigen lateral flow assay for the rapid diagnosis of progressive disseminated histoplasmosis in Colombian patients with AIDS.". Mycoses 63, 139-144. doi: 10.1111/myc.13023

Caceres, D. H., Knuth, M., Derado, G., and Lindsley, M. D. (2019). Diagnosis of progressive disseminated histoplasmosis in advanced HIV: a meta-analysis of assay analytical performance. J. Fungi. 5:E76. doi: 10.3390/jof5030076

Caceres, D. H., Zuluaga, A., Arango-Bustamante, K., de Bedout, C., Tobón, A. M., Restrepo, A., et al., (2015). Implementation of a training course increased the diagnosis of histoplasmosis in Colombia. Am. J. Trop. Med. Hyg. 93, 662-667. doi: 10.4269/ajtmh.15-0108

Cho, S.-H., Yu, Y.-B., Jark, J.-S., Yook, K.-D., and Kim, Y.-K. (2018). Epidemiological characterization of imported systemic mycoses occurred in Korea. Osong. Public Health Res. Perspect. 9, 255-260. doi: 10.24171/j.phrp. 2018.9.5.07

Cottle, L. E., Gkrania-Klotsas, E., Williams, H. J., Brindle, H. E., Carmichael, A. J., Fry, G., et al. (2013). A multinational outbreak of histoplasmosis following a biology field trip in the Ugandan rainforest. J. Trav. Med. 20, 83-87. doi: $10.1111 /$ jtm. 12012

Cunningham, L., Cook, A., Hanzlicek, A., Harkin, K., Wheat, J., Goad, C., et al. (2015). Sensitivity and specificity of Histoplasma antigen detection by enzyme immunoassay. J. Am. An. Hosp. Assoc. 51, 306-310. doi: 10.5326/JAAHA-MS6202

Denning, D. W. (2016). Minimizing fungal disease deaths will allow the UNAIDS target of reducing annual AIDS deaths below 500000 by 2020 to be realized. Philos. Trans. R. Soc. Lond. B Biol. Sci. 371:20150468. doi: 10.1098/rstb.2015. 0468

Deppen, S. A., Massion, P. P., Blume, J., Walker, R. C., Antic, S., Chen, H., et al. (2019). Accuracy of a novel histoplasmosis enzyme immunoassay to evaluate suspicious lung nodules. Cancer Epidemiol. Biomarkers Prev. 28, 321-326. doi: 10.1158/1055-9965.EPI-18-0169

Doleschal, B., Rödhammer, T., Tsybrovskyy, O., Aichberger, K. J., and Lang, F. (2016). Disseminated histoplasmosis: a challenging differential diagnostic consideration for suspected malignant lesions in the digestive Ttact. Case Rep. Gastroenterol. 10, 653-660. doi: 10.1159/000452203

Fandiño-Devia, E., Rodríguez-Echeverri, C., Cardona-Arias, J., and Gonzalez, A. (2016). Antigen detection in the diagnosis of histoplasmosis: a meta-analysis of diagnostic performance. Mycopathologia 181, 197-205. doi: 10.1007/s11046015-9965-3

Gago, S., Esteban, C., Valero, C., Zaragoza, O., Puig De La Bellacasa, J., and Buitrago, M. J. (2014). A multiplex real-time PCR assay for identification of Pneumocystis jirovecii, Histoplasma capsulatum, and Cryptococcus neoformans/Cryptococcus gattii in samples from AIDS patients with opportunistic pneumonia. J. Clin. Microbiol. 52, 1168-1176. doi: 10.1128/JCM.02895-13

Gajurel, K., Dhakal, R., and Deresinski, S. (2017). Histoplasmosis in transplant recipients. Clin. Transplant. 31:e13087. doi: 10.1111/ctr.13087

Gómez, L. F., Arango, M., McEwen, J. G., Gómez, O. M., Zuluaga, A., Peláez, C. A., et al. (2019). Molecular epidemiology of Colombian Histoplasma capsulatum isolates obtained from human and chicken manure samples. Heliyon 5:e02084. doi: 10.1016/j.heliyon.2019.e02084

Gómez, L. F., Torres, I. P., Jiménez-A, M. P., McEwen, J. G., de Bedout, C., Peláez, C. A., et al. (2018). Detection of Histoplasma capsulatum in organic fertilizers by Hc100 nested polymerase chain reaction and Its correlation with the physicochemical and microbiological characteristics of the samples. Am. J. Trop. Med. Hyg. 98, 1303-1312. doi: 10.4269/ajtmh.17-0214

Guedes, H. L. M., Guimarães, A. J., Muniz, M. M., Pizzini, C. V., Hamilton, A. J., and Peralta, J. M. (2003). PCR assay for identification of Histoplasma capsulatum based on the nucleotide sequence of the $\mathrm{M}$ antigen. J. Clin. Microbiol. 41, 535-539. doi: 10.1128/jcm.41.2.535-539.2003

International Organization for Migration (2018). Migration and Migrants: A Global Overview. World Migration Report 2018. Geneva: International Organization for Migration.

Kamei, K., Sano, A., Kikuchi, K., Makimura, K., Niimi, M., Kazuo Suzuki, K., et al. (2003). The trend of imported mycoses in Japan. J. Infect. Chemother. 9, 16-20. doi: 10.1007/s10156-002-0217-3

Kauffman, C. A. (2009). Histoplasmosis. Clin. Chest. Med. 30, 217-225. doi: 10 1016/j.ccm.2009.02.002 
Lee, P. L. M. (2017). DNA amplification in the field: move over PCR, here comes LAMP. Mol. Ecol. Resour. 17, 138-141. doi: 10.1111/1755-0998.12548

Lindner, A. K., Rickerts, V., Kurth, F., Wilmes, D., and Richter, J. (2018). Chronic oral ulceration and lip swelling after a long term stay in Guatemala: a diagnostic challenge. Trav. Med. Infect. Dis. 23, 103-104. doi: 10.1016/j.tmaid.2018.04.009

López, L. F., Muñoz, C. O., Cáceres, D. H., Tobón, A. M., Loparev, V., Clay, O., et al. (2017). Standardization and validation of real time PCR assays for the diagnosis of histoplasmosis using three molecular targets in an animal model. PloS One 12:e0190311. doi: 10.1371/journal.pone.0190311

Loulergue, P., Bastides, F., Baudouin, V., Chandenier, J., Mariani-Kurkdjian, P., Dupont, B., et al. (2007). Literature review and case histories of Histoplasma capsulatum var. duboisii infections in HIV-infected patients. Emerg. Infect. Dis. 13, 1647-1652. doi: 10.3201/eid1311.070665

Manfredi, R., Mazzoni, A., Nanetti, A., and Chiodo, F. (1994). Histoplasmosis capsulati and duboisii in Europe: the Impact of the HIV pandemic, travel and immigration. Eur. J. Epidemiol. 10, 675-681. doi: 10.1007/BF017 19280

Martagon-Villamil, J., Shrestha, N., Sholtis, M., Isada, C. M., Hall, G. S., Bryne, T., et al. (2003). Identification of Histoplasma capsulatum from culture extracts by real-time PCR. J. Clin. Microbiol. 41, 1295-1298. doi: 10.1128/jcm.41.3.12951298.2003

Maubon, D., Simon, S., and Aznar, C. (2007). Histoplasmosis diagnosis using a polymerase chain reaction method. application on human samples in French Guiana, South America. Diagn. Microbiol. Infect. Dis. 58, 441-444. doi: 10.1016/ j.diagmicrobio.2007.03.008

Molina-Morant, D., Sánchez-Montalvá, A., Salvador, F., Sao-Avilés, A., and Molina, I. (2018). Imported endemic mycoses in Spain: evolution of hospitalized cases, clinical characteristics and correlation with migratory movements, 1997-2014. PLoS Negl. Trop. Dis. 12:e0006245. doi: 10.1371/ journal.pntd.0006245

Muraosa, Y., Toyotome, T., Yahiro, M., Watanabe, A., Shikanai-Yasuda, M. A., and Kamei, K. (2016). Detection of Histoplasma capsulatum from clinical specimens by cycling probe-based real-time PCR and nested real-time PCR. Med. Mycol. 54, 433-438. doi: 10.1093/mmy/myv106

Nacher, M., Blanchet, D., Bongomin, F., Chakrabarti, A., Couppié, P., Demar, M., et al. (2018). Histoplasma capsulatum antigen detection tests as an essential diagnostic tool for patients with advanced HIV disease in low and middle income countries: a systematic review of diagnostic accuracy studies. PLoS Negl. Trop. Dis. 12:e0006802. doi: 10.1371/journal.pntd.0006802

Norman, F. F., Martín-Dávila, P., Fortún, J., Dronda, F., Quereda, C., SánchezSousa, A., et al. (2009). Imported histoplasmosis: two distinct profiles in travelers and immigrants. J. Trav. Med. 16, 258-262. doi: 10.1111/j.1708-8305. 2009.00311.x

Oladele, R. O., Ayanlowo, O. O., Richardson, M. D., and Denning, D. W. (2018) Histoplasmosis in Africa: an emerging or a neglected disease? PLoS Negl. Trop. Dis. 12:e0006046. doi: 10.1371/journal.pntd.0006046

Panda, A., Ghosh, A. K., Mirdha, B. R., Xess, I., Paul, S., Samantaray, J. C., et al. (2015). MALDI-TOF mass spectrometry for rapid identification of clinical fungal isolates based on ribosomal protein biomarkers. J. Microbiol. Methods 109, 93-105. doi: 10.1016/j.mimet.2014.12.014

Peigne, V., Dromer, F., Elie, C., Lidove, O., Lortholary, O., and French Mycosis Study Group. (2011). imported acquired immunodeficiency syndrome-related histoplasmosis in metropolitan France: a comparison of pre-highly active antiretroviral therapy and highly active anti-retroviral therapy eras. Am. J. Trop. Med. Hyg. 85, 934-941. doi: 10.4269/ajtmh.2011.11-0224

Richaud, C., Chandesris, M. O., Lanternier, F., Benzaquen-Forner, H., GarciaHermoso, D., Picard, C., et al. (2014). Case report: imported african histoplasmosis in an immunocompetent patient 40 years after staying in a disease-endemic area. Am. J. Trop. Med. Hyg. 91, 1011-1014. doi: 10.4269/ ajtmh.13-0731

Rickerts, V., Bialek, R., Tintelnot, K., Jacobi, V., and Just-Nübling, G. (2002). Rapid PCR-based diagnosis of disseminated histoplasmosis in an AIDS patient. Eur. J. Clin. Microbiol. Infect. Dis. 21, 821-823. doi: 10.1007/s10096-002-0833-y

Rizzato, C., Lombardi, L., Zoppo, M., Lupetti, A., and Tavanti, A. (2015). Pushing the limits of MALDI-TOF mass spectrometry: beyond fungal species identification. J. Fungi. 1, 367-383. doi: 10.3390/jof1030367
Rothenburg, L., Hanzlicek, A. S., and Payton, M. E. (2019). A monoclonal antibody-based urine Histoplasma antigen enzyme immunoassay (IMMY\$) for the diagnosis of histoplasmosis in cats. J. Vet. Intern. Med. 33, 603-610. doi: $10.1111 /$ jvim. 15379

Rubio-Carrasquilla, M., Santa, C. D., Rendón, J. P., Botero-Garcés, J., Guimarães, A. J., Moreno, E., et al. (2019). An interferon gamma release assay specific for Histoplasma capsulatum to detect asymptomatic infected individuals: a proof of concept study. Med. Mycol. 57, 724-732. doi: 10.1093/mmy/my y131

Rychert, J., Slechta, E. S., Barker, A. P., Miranda, E., Babady, N. E., Tang, Y. W., et al. (2018). Multicenter evaluation of the Vitek MS v3.0 System for the identification of filamentous fungi. J. Clin. Microbiol. 56, e1353-e1317. doi: 10.1128/JCM. 01353-17

Salzer, H. J. F., Stoney, R. J., Angelo, K. M., Rolling, T., Grobusch, M. P., Michael Libman, M., et al. (2018). Epidemiological aspects of travel-related systemic endemic mycoses: a GeoSentinel analysis, 1997-2017. J. Trav. Med. 25:tay055. doi: 10.1093/jtm/tay055

Scheel, C. M., Zhou, Y., Theodoro, R. C., Abrams, B., Balajee, S. A., and Litvintseva, A. P. (2014). Development of a loop-mediated isothermal amplification method for detection of Histoplasma capsulatum DNA in clinical samples. J. Clin. Microbiol. 52, 483-488. doi: 10.1128/JCM.02739-13

Schlagenhauf, P., Weld, L., Goorhuis, A., Gautret, P., Weber, R., von Sonnenburg, F., et al. (2015). Travel-associated infection presenting in Europe (2008-12): an analysis of EuroTravNet longitudinal, surveillance data, and evaluation of the effect of the pre-travel consultation. Lancet Infect. Dis. 15, 55-64. doi: 10.1016/S1473-3099(14)71000-X

Segel, M. J., Lindsley, M. D., Rozenman, J., Schwartz, E., Berkman, N., Neuberger, A., et al. (2015). Histoplasmosis in Israeli travelers. Am. J. Trop. Med. Hyg. 92, 1168-1172. doi: 10.4269/ajtmh.14-0509

Simon, S., Veron, V., Boukhari, R., Denis Blanchet, D., and Aznar, C. (2010). Detection of Histoplasma capsulatum DNA in human samples by real-time polymerase chain reaction. Diagn. Microbiol. Infect. Dis. 66, 268-273. doi: 10. 1016/j.diagmicrobio.2009.10.010

Staffolani, S., Buonfrate, D., Angheben, A., Gobbi, F., Giorli, G., Guerriero, M., et al. (2018). Acute histoplasmosis in immunocompetent travelers: a systematic review of literature. BMC Infect. Dis. 18:673. doi: 10.1186/s12879-0183476-z

Staffolani, S., Riccardi, N., Farina, C., Lo Cascio, G., Gulletta, M., and Federico Gobbi, F. (2020). Acute histoplasmosis in travelers: a retrospective study in an Italian referral center for tropical diseases. Pathog. Global Health doi: 10.1080/ 20477724.2020.1716517 [Epub ahead of print].

Theel, E. S., Jespersen, D. J., Harring, J., Mandrekar, J., and Binnicker, M. J. (2013). Evaluation of an enzyme immunoassay for detection of Histoplasma capsulatum antigen from urine specimens. J. Clin. Microbiol. 51, 3555-3559. doi: 10.1128/JCM.01868-13

Torres-González, P., Niembro-Ortega, M. D., Martínez-Gamboa, A., Ahumada-Topete, V. H., Andrade-Villanueva, J., Javier Araujo-Meléndez, J., et al. (2018). Diagnostic accuracy cohort study and clinical value of the Histoplasma urine antigen (ALPHA Histoplasma EIA) for disseminated histoplasmosis among HIV infected patients: a multicenter study. PLoS Negl. Trop. Dis. 12:e0006872. doi: 10.1371/journal.pntd.000 6872

UNWTO (2019). International Tourism Highlights. International Tourism Continues to Outpace the Global Economy. Available online at: https:// www.e-unwto.org/doi/pdf/10.18111/9789284421152?download=true (accessed November 10, 2019).

Valero, C., Buitrago, M. J., Gago, S., Quiles-Melero, I., and GarcíaRodríguez, J. (2018). A matrix-assisted laser desorption/ionization time of flight mass spectrometry reference database for the identification of Histoplasma capsulatum. Med. Mycol. 56, 307-314. doi: 10.1093/mmy/my $\mathrm{x} 047$

Vasconcellos, I. C. S., Dalla Lana, D. F., and Pasqualotto, A. C. (2019). The role of molecular tests in the diagnosis of disseminated histoplasmosis. J. Fungi. 6:E1. doi: $10.3390 /$ jof 6010001

Wheat, L. J. (2003). Current diagnosis of histoplasmosis. Trends Microbiol. 11, 488-494. doi: 10.1016/j.tim.2003.08.007 
Wheat, L. J., Azar, M. M., Bahr, N. C., and Spec, A. (2016). Histoplasmosis. Infect. Dis. Clin. North Am. 30, 207-227. doi: 10.1016/j.idc.2015. 10.009

Woods, G. L., and Schnadig, V. J. (2003). "Histopathology of fungal infections, in Clinical Mycology, eds E. J. Anaissie, M. R. McGinnis, and M. A. Pfaller 1st Edn, Philadelphia: Churchill Livigston, 80-95.

Zatti, M. S., Arantes, T. D., Fernandes, J. A. L., Bay, M. B., Milan, E. P., Naliato, G. F. S., et al. (2019). Loop-mediated isothermal amplification and nested PCR of the internal transcribed spacer (ITS) for Histoplasma capsulatum detection. PLoS Negl. Trop. Dis. 13:e0007692. doi: 10.1371/journal.pntd.0007692
Conflict of Interest: The authors declare that the research was conducted in the absence of any commercial or financial relationships that could be construed as a potential conflict of interest.

Copyright (c) 2020 Buitrago and Martín-Gómez. This is an open-access article distributed under the terms of the Creative Commons Attribution License (CC BY). The use, distribution or reproduction in other forums is permitted, provided the original author(s) and the copyright owner(s) are credited and that the original publication in this journal is cited, in accordance with accepted academic practice. No use, distribution or reproduction is permitted which does not comply with these terms. 